\title{
"BROADWAY, THE MAGNIFICENT!" A NEWLY DISCOVERED WHITMAN ESSAY
}

\author{
JEROME LOVING
}

UNTIL NOW IT HAS BEEN thought that Whitman's last contribution to Life Illustrated appeared on August 30, $1856 .{ }^{1}$ Life Illustrated, a highly successful literary and cultural magazine, was published by Fowler and Wells, the phrenologists who sponsored the publications of the first and second editions of Leaves of Grass. Recently, David S. Reynolds has pointed out that Samuel R. Wells tried to back out of publishing the second edition because of mixed reviews of the first edition, especially one by Rufus Wilmot Griswold which hinted (though in Latin) at a homosexual theme in one or more of the twelve poems. In his letter of June 7, 1856, Wells asked for "the omission of certain objectionable passages," saying that he and his partner could give "twenty reasons." 2 Yet they did publish the second edition in September of that year. Since there were no significant changes made in the original twelve poems, besides the addition of titles to the previously untitled poems, the objectionable passages must have been part of the twenty poems that were added to Leaves of Grass in 1856 . We can only speculate what poems Wells referred to. No doubt he (or others) found objectionable passages in "Poem of Procreation" ("A Woman Waits For Me") and "Bunch Poem" ("Spontaneous Me"). Whitman must have toned down these and other new poems because Wells had threatened Whitman in his letter that without this self-censorship or expurgation (Whitman's first?), they would decline to bring out the second edition.

Fowler and Wells did not end their relationship with Whitman there, however, for the poet published "Broadway, the Magnificent!" in Life Illustrated of November 8, 1856. Although he was occasionally nervous about Whitman's poetry, Wells did not express personal disapproval, merely fear of public disapproval for publishing Whitman's sexy poems. Saying curiously that their firm was not "in favor" with the "conservatism" of the day, they thought Whitman (whom Wells addressed as "Friend Whitman") would do better with another house, and recommended the Masons, the publishers of Sara Parton ("Fanny Fern"). "Broadway, the Magnificent," on the other hand, presented no problems. It is a spirited, historical piece, which evokes the present-day as well as past excitement of Manhattan's oldest street, originally an Indian trail. The essay reflects the poet's inexhaustible love for a street 
and a city he visited regularly while living in Brooklyn and to which he returned from Washington whenever visiting his mother. Whitman had already published "Broadway" in his "New York Dissected" series for Life Illustrated on August 9, 1856, and Leaves of Grass contains three poems about Broadway, including "A Broadway Pageant," which is not mainly about the street but the establishment of diplomatic relations with Japan. Whitman also alluded to the avenue in several prose pieces, including Specimen Days (1883), but this newly discovered essay may be his best work on the subject because it is not merely a catalog of types and places but a meditation of sorts. ${ }^{3}$ Its theme is similar to that of the poem "Broadway," published in the New York Herald of April 10, 1888. In the poem, he compares Broadway to a great river ("What hurrying human tides, or day or night! / What passions, winnings, losses, ardors, swim thy waters!"). In "Broadway, the Magnificent!" the river is the Mississippi, which the poet had traveled with his young brother Jeff in 1848 when they lived for three months in New Orleans. Now Broadway is hailed as "that mighty ever-flowing land-river, pouring down through the center of Manhattan Island!" Whitman also touches upon the "darker, bloodier history" of Broadway, not only the British occupation of New York between 1776 and 1883, but the slave revolt of 1741 . Here he shows the kind of sympathy for black people suggested in Martin Klammer's Whitman, Slavery, and the Emergence of Leaves of Grass (1995).

Like all of Whitman's other contributions to Life Illustrated (including all those attributed to him in New York Dissected), "Broadway, the Magnificent!" is not signed. The evidence for his authorship depends mainly on its characteristic style (the long, flowing sentences cataloging the sights of the street) and its theme that Broadway was an exercise in democracy. He also quotes (and misquotes; see note 12) from William Cullen Bryant's "The Crowded Street" (1843); Bryant, of course, was Whitman's favorite poet (besides himself). Whitman seems to have manipulated Bryant's poem so that it underscored his idea that loneliness is also one of the many emotions found on Broadway. Here, then, is Whitman's essay as it appeared in Life Illustrated.

\section{BROADWAY, THE MAGNIFICENT!}

As it is to-day and to-night, As it was a century ago, and As it was two centuries ago.

Broadway! that mighty ever-flowing land-river, pouring down through the center of Manhattan Island! A slender, solid bed, paved with granite blocks,its side-banks of marble, iron, plate-glass, brick, and wood-its broad trottoirsthe priceless wealth lavished every where with unsparing hand, heedlessly 
poured in its huge windows, or seen through its wide-open doors-the pictures, jewelry, silks, furs, costly books, sculptures, bijouterie, plate, china, cutglass, fine cloths, fabrics of linen, curious importations from far-off Indian seas, grotesque wooden figures made in Japan, bronze groups painfully true to life, a deer struck by the hunter, a dying bird, the Madonna, the Crucifixion, superb engravings, photographs, landscapes, historic groups,-each bearing a part in the most stately exhibition of magnificent Broadway.

It continually runs there between its banks, ebbing and flowing with American men, women, and with strangers. There they pass, a hundred thousand a day, - sometimes two hundred thousands; - there have even been five hundred thousand different people in Broadway in one day. This last, on the occasion of some great event, the President, Kossuth, ${ }^{4}$ or the like.

The ships! the fleets of humanity, gliding up and down Broadway! Day and night, day and night, some bound one way, some another!

Come, reader, you shall saunter with us an hour-it will be a salutary lesson. We leap with you at once to the lower end of Broadway at the Battery, and begin there-first politely giving you our arm, to hook your wrist through, dear sir, dear madam, or dear child, it matters not.

The old trees still look thrifty on the Bowling Green. The iron fence around is bereft of the crowns that once adorned the posts; they were removed by the Liberty Boys in 1775; also the leaden statue of King George was melted into bullets for the Battle of Brooklyn in $1776 .{ }^{5}$ You can still see on the posts where the king's insignia have been cut off by the cold chisel and the hammer.

This corner house, the first in the street, is one of the few old memorials of New York architecture; it is a hundred years old. After the gloomy defeat at Brooklyn, when the British took possession of New York, this house was the head-quarters of Sir Guy Carlton; and after him of other British commanders. Here was heard the music of many a loyal festivity during the Revolutionary war,- - for the king's men held this city throughout. Yet most likely from this house, drooping and baffled, withdrew to their boats the last British group of distingushed persons, on the evacuation of the royal army. The garden of the house ran down to the river. Afterwards, in a tenement built upon the grounds, occurred the death of Fulton.

Old Broadway! That is to say, Broadway under, and immediately following, the Dutch administrations; because this great avenue holds the farthest American antiquity. It was then of course an unpaved road, with many things upon it, or in sight of it, that would now appear very curious; it was called "De Heere Straat"-viz., the principal or master street. It had a whipping-post, cage, pillory, and stocks. Not far from its borders, near where Wall street now is, was a market for the sale of Indian slaves and negroes. ${ }^{6}$ This was about two hundred years ago. There was also a gallows, but that stood a little ways out of town.

There was an invasion apprehended from the Yankees, who were then, as now, the same pushing and stirring race; so the Dutch built a wall or embankment, of palisades, posts six feet apart, sided with boards, raised with earth, strengthened by two stone bastions- the whole extending from the East to the North river. Such was the origin of the name of Wall street - the tremendous protection just mentioned being on that locality. The shore where the Battery now is was made terrible by a regular castellated fort. 
The name of Broadway was given to the street by the English, long enough ago to warrant us in calling it indeed Old Broadway. A little more than a hundred years since, it was a charming old street, with fine trees. Where the fountain now is, in the Park, was an old windmill, quite out of town. There were walks, banks, lanes, commons, cow-pastures, cow-tracks, and so on.

But Old Broadway has a darker, bloodier history. There was the Negro Plot, in 1741. Eighty-three persons, mostly blacks, were either burnt at the stake, hanged, transported, or sold into slavery for a conspiracy to destroy the city. One of the stakes where the poor victims were burnt was at the junction of Wall street and Broadway.

You who come down town to business in the morning! you little think of the horrid spectacle that corner more than once exhibited! the iron pillar-the chains - the fagots of dry wood and straw-the African negro in the middlethe pile touched off-the yells and howls and agonized shrieks-the crowd around stolid and indifferent. ${ }^{7}$

Washington lived in Broadway while he was President, the first term. His house was on the south side, about three hundred feet up from the Bowling Green. Washington is much identified with Broadway. Up this street, with despair in his heart, he retreated after the Battle of Brooklyn, August, 1776, closely followed by the British. Here, too, he afterwards was the principal figure in more than one procession of welcome and triumph. ${ }^{8}$

Thus slowly pausing and gossiping, we advance toward the crush of Broadway as it now is-Broadway to-day. These immense and elegant structures from Wall street, onward and onward many a block, are all for purposes of trade; the old fashionable residences have given place - they are pulled down, one after another. Five, six, and seven stories high the new buildings tower up-while down, down, far down in the earth, descend their vast, dusky, subterranean, apartments stored with goods. Along here are the round world's messengers, the various Express offices. The light and strong wagons are backed up in slanting diagonal lines before the doors-sometimes a score of wagons, sometimes two or three score; the horses swift, docile, powerful-the drivers the noblest specimens of American young men. What piles of baggage, trunks, bales, goods of a thousand various kinds, are heaped up on these wagons! Some depart-others arrive. The porters assist the drivers-they drag mighty tons of cases over the walk, as if they were but ladies workboxes.

Here are stores for goods made of preparations or India-rubber or guttapercha. Water-proof wearing apparel, coats, trowsers, hats, boots-life preservers, seats, bottles, numberless different toys, many useful implementsall of this modern preparation.

Shops for sportsmen, and for warlike persons; in the windows desperatelooking knives, with blades eighteen inches long - choice fowling-pieces, sixbarreled pistols, rifles, revolvers, and the like; - also fishing apparatus, very curious and complicated,- - rod, cords, reels, flies, worms, insects and reptiles, curiously fashioned, the like certainly never seen except in those shops for sportsmen.

Depots of gentlemen's toilet articles-very amazing to simple persons-exhibiting a great array of brushes, razors, tweezers, little looking glasses, immense combs, mysterious cutlery, bunches of toothpicks, sheepskin things, white puffy things, ivory things, hair oils, hair dyes, sponges large and small, 
perfumes,- and all these only the beginning to long shelves and heaps beyond.

Every little while, a drug store-rich with the finest plate glass, and the traditional colored water in globes in the windows-inside showing china jars, bottles, gallipots, the silver soda-water spout, the white marble counter, the very floor paved with marble-every object clean, bright, sparkling, glittering like so many snakes.

Elegant, large, tasty shops for men's hats- "the latest styles," neatly promulged on pegs, in the windows; black hats, white hats, hats of mousecolor, claret color, gamboge, rose-leaf, - hats of all textures, shapes, sizeshats of all nations, some with much pretence, others modest - some with such an air of effrontery that they easily make the greatest coward look like a great border ruffian.

Bookstores are planting themselves rapidly on Broadway-and publishers the same. Here we see whole libraries in the windows, sometimes a book opened at an illustration; here a row of curious imported books, French, German, Spanish, Italian; here again costly pictorial works, atlases, books of antiquities, and so on.

Clothing, carpeting, pianos, wigs, laces, curtains, the Museum, the Theatre, the City Hall, the far-famed democratic Tammany Hall in sight, the Astor House, Stewart's, Bowen \& McNamee's new store, the City Hospital, our own modest place of business, ${ }^{9}$ Williams \& Stevens's, the Tabernacle, the numerous photograph and ambrotype establishments, political head-quarters, banks, cellars for lager-beer, oyster-saloons, billiard-saloons, ten-pin alleys, Taylor's, the St. Nicholas Hotel, the Metropolitan, Laura Keene's Varieties, the different minstrels, immense stores for mirrors and oil paintings, mourning stores, cabinet furniture, millinery, stoves, carriages, cloaks and capes, gas fixtures and chandeliers, - these, and a hundred times these, are but a drop in the multitudinous sights we see as we walk along this wonderful avenue, whose like is certainly to be found in no other city upon earth.

Between the sidewalks, continually roll the omnibuses - tens, hundreds, thousands of them. The drivers, on their boxes, sharply look out for passengers, interrogating all with crooked fingers; ${ }^{10}$ till getting the coveted twelve, off they dash, up or down, with a celerity and safety, threading the close jam of vehicles, certainly by inspiration,-- for nothing else could accomplish what a Broadway omnibus driver hourly accomplishes, careering rapidly with a stage full of passengers.

Occasionally a huge truck comes slowly rumbling along, with four horsesfrom the long beam swinging a great block of granite, or iron boiler, or some other ponderous load, wagging heavily, suspended by strong chains of iron.

Omnibuses, trucks, express wagons, hotel coaches, private carriages, the light one-horse carriage, occasionally some persons on horseback, cabs, carts, market-wagons, loads from factories, butchers' carts, and thousands upon thousands besides of heterogeneous vehicles, old and new, heavy and light, bright and rusty, keep up the vehicular current of Broadway, between the sidewalks. The tramp of the horses, the voices of the drivers, the rattle of wheels, the confusion, stoppages, expletives, excitement, are such as only Broadway can exhibit. 
Military parades have to show themselves on Broadway, of course; target excursions, firemen's processions, and all such turn outs, the same. We hear the music from a distance, the drums beating, the loud clear tones of the bugles-we see three or four policemen hurrying along in advance to turn off the stages and carts - the pioneers heave in sight with their big caps-and directly the procession is upon us. We stop at the curbstone, listen to the band, look with pleasure on the fine muscular forms of the New York young men, and resume our walk and our study.

$\mathrm{Ah}$, could we ever exhaust the amusement of Broadway? the profound lessons of Broadway? What need of poring over books, in pursuit of that puzzle human nature, when here is a living, moving, walking, speaking explication of the puzzle? ${ }^{11}$

"How fast the flitting figures come! The mild, the fierce, the stony face, Some bright with thoughtless smiles, and some Where secret tears have left their trace.

"Youth, with pale brow and slender frame, And dreams of greatness in thine eye, Goest thou to build an early name?

Or early in thy task to die?

"Keen son of trade, with eager brow, Who is now fluttering in thy snare? Thy golden fortunes- tower they now?

Or melt the glittering shapes to air?

"Who of this crowd to-night shall tread The dance till daylight gleam again? Who sorrow o'er the untimely dead? Who writhe in throes of mortal pain?

Some, famine-struck, shall think how long The cold, dark hours - how slow the light; And some who flaunt amid the throng, Shall hide in dens of shame to-night.

"And some who walk in calmness here, Shall shudder as they reach the door, Where one who made their dwelling dear Its light, its life, is seen no more."

\section{Bryant's "Crowded Street"12}

It is not all inspiring and enlivening, the sentiment of Broadway; there is a little of melancholy also. How thoughtless! how frivolous! how little of earnest manhood and womanhood there is here! Or, if earnest, how spare a portion is bent toward noble aims, - toward freedom, simplicity, purity, power! How 
little has reference to the inevitable - to the future life-to the next generation - to the rising grandeur and beneficence of America!

Then Broadway at night! This night, you, dear sir, madam, or child, now walking arm in arm with our fancy, will perhaps sleep in some quiet farmhouse in Canada, Ohio, Missouri, California, or Texas; - but what a glare and hubbub in Broadway, the while! A million jets of gas-light, indoors and outin the theatres, in the exhibitions, in the stores, in parlors, in saloons, over the bars in bar-rooms, in the gambling houses, - ah, in such unnamable places! Crowds of elegantly dressed persons, on their way to some pleasure,-ah, returning from some pleasures; citizens, foreigners, country-people, youths, honest persons, dishonest, pickpockets, beggars, street-musicians.

When our distant friend has visited New York, asking us to direct him to notable places, amusements, studies, curiosities, we have been in the habit of naming the choicest exhibitions, lectures, the opera, or some speaker, or celebrity. But henceforth we will take our friend to the starting point of the great avenue of this Island, by the Bowling Green, and point him on his way upward along the tumultuous banks and currents. If he have an hour to occupy he can do it well; or if he have a week, he can occupy it well; or if he have years and years, Broadway will never fail in riches, arts, men, women, histories, stately shows, morals, warnings, wrecks, triumphs - the profoundest indices of mortality and immortality.

\section{Texas AEM University}

\section{NOTES}

1 "The Circus," reprinted in New York Dissected, ed. Emory Holloway and Ralph Adimari (New York: Rufus Rockwell Wilson, Inc., 1936), 183-185; see also William White, "Walt Whitman's Journalism: A Bibliography," Walt Whitman Review, 14 (September, 1968), 130.

2 Walt Whitman's America: A Cultural Biography (New York: Alfred A. Knopf, 1995), 348, where the letter is misdated as June 17; Wells's letter to Whitman is in the Feinberg Collection, Library of Congress. The text, written on Life Illustrated letterhead, reads as follows: "After 'duly considering,' we have concluded that it is best for us to insist on the omission of certain objectionable passages in Leaves of Grass, or, decline publishing it. We could give twenty reasons for this, but, the fact will be enough for you to know. We are not in a position, at present, to experiment. We must not venture. Again, it will be better for you to have the work published by clean hands, i.e., by a House, not now committed to onpopular notions. We are not in favor, with the conservatism, and a more orthodox house would do better for you. Try the Masons, Parton's publishers, (they publish Fanny Fern's work). They are rich \& enterprizing, \& I guess would publish Leaves of Grass on fair terms."

3 See New York Dissected, 222, n. 11, for Whitman's other studies of Broadway in his 1840 s journalism as well as a preliminary sketch of a poem.

4 Louis Kossuth, Hungarian patriot who led his country's unsuccessful quest for independence from Austria in the European revolutions of 1848. 
5 See Uncollected Poetry and Prose of Walt Whitman, ed. Emory Holloway (New York: Doubleday, 1921), 2:236-245, for Whitman's discussion of the infamous prison ship where American prisoners of war starved to death after their defeat at the Battle of Long Island, August 27, 1776 (No. 5 of his "Brooklyniana," published in the Brooklyn Standard between June1861 and November 1862). Following the American defeat, the British occupied New York City for seven years.

6 The slave market was located on the East River at Wall Street.

7 The slave revolt of 1741 was initiated by a white tavern keeper named John Hughson, who persuaded two slaves, Caesar and Prince, to burn their masters' houses as cover for stealing goods he was fencing for them. It involved a six-month trial that was characterized by hysteria and charges of arson, theft, and murder. The result of the episode was that four whites and eighteen slaves were hanged, thirteen other slaves were burnt at the stake, and seventy others were transported to the West Indies and elsewhere.

8 Whitman honored George Washington in "The Sleepers" (1855) by alluding to his farewell speech to his troops at Fraunces' Tavern, after the British had evacuated the city on November 25, 1783 :

Now of the old war-days . . the defeat at Brooklyn;

Washington stands inside the lines . . he stands on the entrenched hills amid a crowd of officers, ...

The same at last and at last when peace is declared,

He stands in the room of the old tavern .... the wellbeloved soldiers all pass through,

The officers speechless and slow draw near in their turns,

The chief encircles their necks with his arm and kisses them on the cheek,

He kisses lightly the wet cheeks one after another . . . . he shakes hands and bids goodbye to the army.

9 According to the letterhead of the June 7, 1856, letter, Life Illustrated was located at 308 Broadway, the same address for Phrenological Cabinet.

10 Cf. the following from "Poem of Walt Whitman, An American" (title of "Song of Myself" in the 1856 edition): "The heavy omnibus, the driver with his interrogating thumb, the clank of the shod horses on the granite floor."

11 Cf. Emerson's statement on books in "The American Scholar" address: "When he can read God directly, the hour is too precious to be wasted in other men's transcripts of their readings."

12 "The Crowded Street" first appeared in Graham's Magazine in March 1843; it was also available in Bryant's Poems (1849). Whitman omitted the first stanza, three stanzas following Bryant's second stanza, and the final two stanzas. He replaced the final stanza with Bryant's fifth stanza, which he had originally skipped when he came to its original placement in the poem. Also, the transcription is generally imprecise with different punctuation and word changes, e.g., "brow" for "cheek" in Bryant's sixth stanza and "light" for "flower" in his fifth stanza (Whitman's last). 